\title{
THE USES OF PSYCHOLOGY IN WAR-TIME
}

\author{
By DR. C. S. Myers, C.B.E., F.R.S.
}

DSYCHOLOGY and three of its applied branches -medical, educational and industrial psychology - have made enormous strides since the War of 1914-18. In 1914 these branches were in their infancy ; to-day they may be said to have passed their adolescence. Indeed, industrial psychology has so widely developed that the term has become a misnomer. It is now concerned with all occupations, and (in developing vocational guidance) even with pre-occupational life : it should be styled 'occupational psychology'. In 1914 tests of intelligence were only just coming into general use in the medical and educational worlds. Now they are officially recognized by the Ministry of Health, the Board of Education and the Board of Control.

\section{Medical Psychology}

In 1914 our present attitude towards the psychoneuroses ('functional' nervous disorders) and their treatment was only just developing. To-day that attitude is approaching stabilization, with maturer experience and the mellowing and blending of certain early crudities of the rival Austrian, French, German and Swiss schools. During the early years of the War of 1914-18 a 'shell-shocked' soldier wandering from his post in a psychoneurotic fugue (or trance) was regarded by Army disciplinarians either as a deserter fit only to be shot for his crime or as a madman certifiable as insane and destined for a lunatic asylum. But by the end of 1916 special hospitals for the reception of cases of war-neurosis and for their psychological treatment by medical specialists had been established in France, both at British bases and in army areas; and similar provision, together with special courses of training for medical officers, was being made at home.

Some of the many lessons learnt have not been forgotten during the present War, although so far the occurrence of war-neuroses has been comparatively rare. To each Army Command throughout Great Britain at the outbreak of war medico-psychological specialists were appointed, acting under a War Office consultant; and a special military hospital was established. A corresponding system was provided for the British Expeditionary Force, and by the Ministry of Health for civilians and soldiers. Intelligence tests, administered by psychologists, are now being officially employed to prevent the retention of men suffering from, or near the border-line of, mental deficiency. The recruitment of men so dull as to make it difficult for them to become satisfactory soldiers has always been a serious problem in war-time. It is especially grave to-day with the increased pace of modern warfare and with the greater skill demanded by a mechanized army. Advice has also been sought by the Admiralty from psychologists during the present War on the improvement of methods for the rejection of the colour-blind.

\section{Aviation Problems}

The psychological laboratories of two British universities are now engaged in research on individual differences in the speed and degree of adaptation of the eye to darkness-a problem of especial concern to the Royal Air Force. For the same fighting service research is also being conducted on other psychological problems of flying, for example, on the kinds of error to which the pilot is most liable when subject to the stress and fatigue occasioned by prolonged periods of flying 'blind'. Other experiments having a war-time reference are also being carried out in psychological laboratories, for example, concerning methods of communication and concerning the effects of certain drugs and other chemical substances on mental efficiency.

\section{Vocational Guidance and Selection}

I well remember visiting one of our most distinguished mathematicians during the last War at Boulogne in 1915. I found him sorting and counting railway tickets in a small cabin in the marshalling yard of the harbour station! It took some time before his outstanding abilities were utilized in solving the problem of gunnery range-finding. To-day more systematic efforts are being made to avoid such errors of placement. All three of our fighting services are beginning to avail themselves of the psychological principles and methods of vocational guidance and selection which have been developed with increasing success during the past twenty years in choosing the best job for a given applicant and in choosing the best applicant for a given job. Throughout the various commands, army officers are now being trained by civilian psychologists in the application of some of these methods to recruits, so as to help in their selection for commissioned and non-commissioned rank and for special work (for example, driving or gunnery), and to reveal recruits of very low intelligence, within the various arms to which they have already been allocated. This scheme may be usefully extended to recruits before their allocation, to men, no longer recruits, who need 
transfer from work (for example, tank or pioneer) to which they have already been unsuitably allocated, and to the better selection and allocation of officers. To improve present methods, the War Office has recently appointed a small advisory committee of psychologists. The Royal Air Force is, correspondingly, employing civilian psychologists with the object of sorting out recruits already allocated to its air-staff ; the psychological problems of. selection of its ground-staff have as yet scarcely been touched. Tests have also been applied to naval units, and the Admiralty has lately invited a vocational psychologist to survey and to report on its present methods of education.

Several local investigations of a less official and less centralized character have also been carried out by psychologists at the request of army officers specially interested in the grading of recruits and their distribution to specialized work. For example, tests have been devised on behalf of a tank brigade for gunnery and for driving efficiency. The commander of an artillery regiment has invited psychologists to test the intelligence of his recruits, and has used the results to help in selecting such specialists as gun position officers' assistants, range-takers, etc. The intelligence has been tested of large batches of recruits in the Royal Army Medical Corps, whose scores were found to range from 0 to 94 (the maximum possible score being 100); the object of this inquiry being to assist in the classification of recruits and in their selection for special duties demanding a fairly high level of intelligence, including the work of instructors and of noncommissioned officers, and, in the case of the most 'backward' recruits, for an appropriate course of special instruction. At the request of a War Office directorate, the best methods of choosing instructors in a certain kind of technical work have been psychologically investigated; and certain recommendations have been adopted. All such work should lend no support to the current popular fallacy that the psychological methods employed in vocational guidance and selection consist solely in the application of tests. These are, in fact, merely accessories to other systematic methods based on psychological principles. They are invaluable servants, but must never be the masters, of the vocational psychologist.

\section{TRAINING}

During recent years the attention of certain industrial psychologists in Great Britain has been directed to improvements in methods of training. In most factories the novice has hitherto learnt his job and still learns it by passively watching a more expert operative, by listening to such words of explanation and advice as the latter may be willing or able to give while engaged on ordinary production work, and by 'trial and error' during subsequent routine practice. But the industrial psychologist now insists that training must be isolated as far as possible from production; that a 'school' for novices must be separately established ; that the instructor must be most carefully selected; and that the course of training must be systematically planned. He urges this procedure because the expert operative cannot teach satisfactorily while busily engaged on production, and because he often proves a bad teacher, unable to describe what movements he uses or why he uses them, or even believing that he employs certain movements whereas actually he employs others. For the course of systematic instruction installed by the industrial psychologist, the easiest movements and the most advantageous position of parts and tools must have been previously determined. These are demonstrated and taught to the novice, and the reasons for adopting them must be carefully explained to him. As a beginner, he is taught always to inspect his products ; and a 'museum of faults' is placed on exhibition, from which he may learn what errors he is likely to commit, how they may be avoided and how, if they do occur, they may best be dealt with.

These new methods of instruction have produced surprisingly good results. Not only have they enormously shortened the period of training, but they have also vastly improved the efficiency of the novices thus trained. They have proved of especial industrial value in war-time, when, as in many engineering works, unskilled persons are necessarily being engaged to take the place of semi-skilled workers who have had to be transferred to more highly skilled work. With appropriate modifications they appear to be also applicable to certain kinds of military training. But so far, in this connexion, during the present War, psychologists have been mainly employed by the fighting services in devising apparatus which will improve and facilitate training, and in addressing officers on the general principles of the subject, at training centres. Books and articles have also been published on the psychological factors involved in leadership, in propaganda work and in the causation of war.

\section{WORKING CONDITIONS}

Industrial psychology has afforded valuable help to firms engaged on Government contracts, in regard to the arrangement of shifts and the distribution of hours of work and rest-pauses, especially when, at the outset of war, excessive working hours were being urged. It has also helped to solve the difficulties of factory lighting and ventilation caused by the 'black-out', which 
resulted in unusual fatigue, absenteeism and higher labour turnover. For the Red Cross Society and Order of St. John of Jerusalem, an investigation in industrial psychology has been conducted into the easier packing and handling of parcels destined for prisoners of war.

\section{Social Conditions}

Several systematic studies have been and are being conducted by educational and social psycho- logists on the effects on children of evacuation and air-raids ; and other psychological investigations of similar, but wider, social import, under the ægis of one of the Ministries, can be reported.

This account does not by any means exhaust all the services that psychology is giving during the War. But it may serve to show the growing and increasingly recognized military, medical and social, practical value of the subject.

\title{
LA SOCIÉTE DE PHYSIQUE ET D'HISTOIRE NATURELLE DE GENEVE
}

\author{
By Prof. F. E. WeISS, F.R.S.
}

G ENEVA has long been renowned as the home of eminent men of science. Some of these, the de Saussures and the de Candolles, belonged to families which, like the Darwins, have produced several generations of distinguished scientific men. It is no wonder, therefore, that the Physical and Natural History Society of Geneva has a deservedly high reputation, and that its Memoirs find a ready exchange with the publications of most learned societies. Last October the Society celebrated its hundred and fiftieth anniversary, and an account of the meeting of celebration fills the pages of the October number of its proceedings. The centenary celebration in 1890 was naturally made a great occasion and the centenary volume of the Memoirs of the Society contains a number of important scientific papers, as well as a history of the Society prepared by the secretary, Dr. A. H. Wartmann.

Like many learned societies, it had its origin in the desire of a number of men of various professions, but all interested in scientific discoveries, to meet and talk over their observations and theories. They met at first informally and probably at irregular intervals in each other's homes, and their number was for this reason naturally limited. For this reason also there seems to have been some doubt as to the exact time when the Society was founded. It really grew into existence. The first minutes of a meeting are dated August 5, 1791, but M. Vaucher, one of the originators of the Society, gives the date of its foundation as 1790 , and this date has been by common consent accepted. No doubt even before that date the Society had an informal existence, for it possesses a manuscript which is said to have been read at one of its meetings in 1783. From the first minutes of a meeting mentioned above we learn that it met in the house of a M. H. A. Gosse, a pharmacist, and a laureate of the Paris Academy of Sciences. Among those present were L. Jurine, a surgeon and naturalist; J. Tallot, whose interests were geological ; Pastor Jean Pierre Vaucher, head of a boarding-school and an eminent botanist, interested in freshwater Algæ, one of the most well-known of which has since been named after him. Other members who formed the nucleus of the Society, but who were absent from this first meeting, were M. A. Pictet, a lawyer and professor of philosophy, interested in physics and the applied sciences; Colladon, a pharmaceutical chemist, and the botanist Gaudy. This group of young amateurs, as Vaucher called them, was soon joined by other members of senior standing and already distinguished in various branches of science. They included H. B. de Saussure and his son Theodore, François Huber, well known for his researches on the life of bees, Pyramus de Candolle, the eminent botanist, and Henri Boissier, rector of the Academy and in charge of the instruction in applied botany. His natural history collection became the nucleus of the future National History Museum of Geneva.

It was decided to ask the veteran Charles Bonnet, then seventy-one years old, to become the honorary patron of the Society. This for reasons of health he refused. Being further pressed he accepted the position, but he died two years later, leaving a bequest to the Society.

Ordinary meetings of the Society still remained somewhat informal. The host at whose house the meeting was held presided and read a paper which was followed by a general discussion. Observations published in scientific journals were also discussed by the meeting. One of the original members tells us that the discussions were always amicable and that contributions by young members were welcomed and encouraged. Occasionally 